\title{
Updated checklist of pseudoscorpions (Arachnida: Pseudoscorpiones) of Central Europe
}

\author{
Обновленный список можноскорпионов (Arachnida: \\ Pseudoscorpiones) Џентральной Европы
}

\section{Martina Červená, Katarína Krajčovičová, Jana Christophoryová М. Червена, К. Крайчовичева, Я. Христофорова}

Department of Zoology, Faculty of Natural Sciences, Comenius University, Mlynská dolina, Ilkovičova 6, SK-842 15 Bratislava 4 , Slovakia. E-mails: martinacervena.lr@gmail.com, krajcovic.katarina@gmail.com, christophoryova@gmail.com cies.

KEY WORDS: classification, diversity, endemic species, species list, synonymisation, taxonomy, type spe-

КЛЮЧЕВЫЕ СЛОВА: классификация, разнообразие, эндемичные виды, список видов, синонимизация, таксономия, типовые виды.

ABSTRACT: The classification and estimated diversity of the order Pseudoscorpiones of Central Europe are updated. An annotated checklist is adjusted according to the latest taxonomic changes and species synonymisation. The present list provides the pseudoscorpion diversity from eight countries of Central Europe with the following species numbers: Austria (70), Switzerland (64), Czech Republic (38), Germany (50), Hungary (53), Poland (38), Slovenia (33) and Slovakia (57). In total, 125 species belonging to 30 genera and 10 families are documented for Central Europe. Austria and Switzerland represent the countries with the highest species and genera numbers, caused mainly by the occurrence of pseudoscorpions endemic to the Alpine province. The species Neobisium deschmanni (G. Joseph, 1882) is removed from the list of Austrian fauna and is added into the fauna of Slovenia based on correction of the type locality. The state of species diversity for each country of Central Europe is discussed.

How to cite this article: Cervená M., Krajčovičová K., Christophoryová J. 2020. Updated checklist of pseudoscorpions (Arachnida: Pseudoscorpiones) of Central Europe // Arthropoda Selecta. Vol.29. No.2. P.219228. doi: 10.15298/arthsel. 29.2.06

РЕЗЮМЕ: Дана обновленная классификация и оценка разнообразия ложноскорпионов Центральной Европы. Аннотированный список выверен в соответствии с последними таксономическими изменениями и видовой синонимией. В настоящей работе описано разнообразие ложноскорпионов восьми стран Центральной Европы со следующим количеством видов: Австрия (70), Швейцария (64), Чехия (38), Германия (50), Венгрия (53), Польша (38), Словения (33) и Словакия (57). Всего в регионе отмечено 125 видов из 30 родов и 10 семейств. В Австрии и Швейцарии представлено наиболее количество видов и родов ложноскорпионов, вслед- ствие наличия там альпийских эндемиков. После уточнения локализации типового местонахождения Neobisium deschmanni (G. Joseph, 1882) исключен из списка фауны Австрии и включен в список Словении. Обсуждается видовое разнообразие ложноскорпионов каждой страны Центральной Европы.

\section{Introduction}

The catalogue of pseudoscorpions of the World (taxa numbers were calculated to the end of 2012) includes 3533 species belonging to 454 genera and 26 families [Harvey, 2013a, b]. Europe, with more than 760 described species, represents a continent with the greatest pseudoscorpion diversity [Harvey, 2007]. Due to more favourable climatic conditions combined with historical factors, of which the most important is the lack of glaciation during the Pleistocene, the highest pseudoscorpion diversity in Europe occurs mainly in Mediterranean countries [Harvey, 2007]. In addition, the numerous karst systems that exist in the Mediterranean region, are represented by specific troglomorphic species [Harvey, 2007].

The first version of the pseudoscorpion checklist of Central Europe was elaborated by Blick in the year 2000 (for all checklist versions see Blick [2004]). This checklist comprised, according to valid species at that time, 80 species of 26 genera and 10 families. It included data from three countries, namely Austria, Germany, and Switzerland. Two years later, Blick updated the version and added two more countries, Belgium and the Netherlands [Blick, 2004]. Summarising all data, 89 species of 27 genera and 10 families were recorded [Blick, 2004]. The last version comprised 94 species of 27 genera and 10 families from eight countries - Austria, Belgium, the Czech Republic, Denmark, Germany, the Netherlands, Poland and Switzerland [Blick, 2004]. 
Regarding Central Europe, pseudoscorpion research has intensified considerably since 2004 and has led to the discovery of the first species recorded in the countries, such as in Austria [Mahnert, 2011b], Switzerland [Gardini, 2009a; Mahnert, 2011a], the Czech Republic [Christophoryová et al., 2011d], Germany [Muster et al., 2008], Hungary [Kárpáthegyi, 2007a, b; Novák, 2012, 2013, 2015, 2017, 2018; Novák, Kutasi, 2014; Novák, Harvey, 2015], Slovenia [Gardini, 2013, 2014] and Slovakia [Christophoryová et al., 2011a, b, c, d, 2012a; Krajčovičová, Christophoryová, 2017; Krajčovičová et al., 2017; Červená et al., 2018]. Three species were even discovered as new to science, namely Neobisium tothi Novák, 2017 discovered in Hungary by Novák [2017], Chthonius delmastroi Gardini, 2009 and Pseudoblothrus infernus Mahnert, 2011 described in Switzerland [Gardini, 2009a; Mahnert, 2011a].

Since the last version of Central European checklist [Blick, 2004], important taxonomic changes of many taxa have been elaborated. Not only were species widely distributed in Central Europe, such as Ephippiochthonius tetrachelatus (Preyssler, 1790) and Pselaphochernes scorpioides (Hermann, 1804), redescribed [Gardini, 2009b; Nassirkhani, 2018], but also species types with more limited distribution such as Diplotemnus balcanicus (Redikorzev, 1928) [Novák, Harvey, 2015], Geogarypus minor (L. Koch, 1873) [Gardini et al., 2017], Allochernes solarii (Simon, 1898) [Červená et al., 2018] and Neobisium slovacum Gulička, 1977 [Červená et al., 2019].

Extensive taxonomic revision of the genus Ephippiochthonius Beier, 1930 was elaborated by Gardini [2013] based on specimens from Italy, Corsica and the Swiss Canton of Ticino. The species were arranged in two species groups: tetrachelatus and fuscimanus groups, and the species Ephippiochthonius poeninus (Mahnert, 1979) was transferred into the genus Globochthonius Beier, 1931 [Gardini, 2013]. One of the most impressive works containing important taxonomic revisions of the Ephippiochthonius complex was made by Zaragoza [2017]. The revision was based on species from the Iberian Peninsula, the Balearic Islands and Macaronesia, and some previously insufficiently studied characteristics were shown to be taxonomically useful [Zaragoza, 2017]. Zaragoza [2017] raised three taxa, previously treated as subgenera of Chthonius, to generic rank - Ephippiochthonius, Globochthonius and Hesperochthonius Muchmore, 1968. Two new genera were described: Cantabrochthonius Zaragoza, 2017 and Occidenchthonius Zaragoza, 2017, 35 new species were described, and 45 new combinations of species were proposed [Zaragoza, 2017].

Except for the revisions, taxonomic changes were also realised due to species synonymisation. Many species distributed in Central Europe were synonymised, e.g., Chthonius baccettii Callaini, 1980 [Gardini, 2004]; Ephippiochthonius elbanus (Beier, 1963) [Gardini, 2013]; C. diophthalmus Daday, 1888, C. ellingseni
Beier, 1939, C. ksenemani Hadži, 1939 [Gardini, 2014]; Cheiridium tetrophthalmum Daday, 1889 [Harvey, 2011]; Diplotemnus insolitus Chamberlin, 1933 [Novák, Harvey, 2015] and Neobisium biharicum Beier, 1939 [Novák, Hörweg, 2017].

All of the above-mentioned facts lead to the necessity for updating the pseudoscorpion diversity in all Central European countries, including Slovakia, Slovenia, and Hungary, that had not been included in the previous checklist version [Blick, 2004].

\section{Methods}

The present checklist of Pseudoscorpiones of Central Europe is compiled from Blick [2004] and the catalogue of Pseudoscorpions of the World [Harvey, 2013b] and the following papers for individual countries:

Austria (AT): Mahnert [2004, 2011b];

Switzerland (CH): Gardini [2009a], Mahnert [2011a];

Czech Republic (CZ): Christophoryová et al. [2012b];

Germany (DE): Kreissl [1969], Muster et al. [2008], Muster, Blick [2016];

Hungary (HU): Kárpáthegyi [2007a, b], Novák [2012, 2013, 2015, 2017, 2018], Novák, Kutasi [2014], Novák, Harvey [2015]; 2014];

Poland (PL): Rafalski [1967], Jędryczkowski [1985,

Slovenia (SI): Joseph [1882], Gardini [2013, 2014];

Slovakia (SK): Christophoryová et al. [2011b, c, 2012a, b], Krajčovičová, Christophoryová [2017], Krajčovičová et al. [2017], Červená et al. [2018], Hernández-Corral et al. [2018].

The pseudoscorpion list is adjusted according to the latest important taxonomic changes [Gardini, 2013; Zaragoza, 2017] and species synonymisation [Gardini, 2004, 2013, 2014; Harvey, 2011; Novák, Harvey, 2015; Novák, Hörweg, 2017; Harvey et al., 2018]. Nomenclature for all taxa follows Gardini [2013], Harvey [2013b] and Zaragoza [2017]. The year of description of three species - Chthonius heterodactylus Tömösváry, 1883; Geogarypus hungaricus (Tömösváry, 1883) and Lamprochernes chyzeri (Tömösváry, 1883) has been changed according to Judson [2018]. The order of families follows Harvey [1991], and genera and species are listed alphabetically under each family. Sub-species have not been considered.

The synonymised species are listed below with references and abbreviations for individual countries (since the last checklist version of Central Europe in Blick [2004]):

AT: Chthonius ellingseni was synonymised with $C$. raridentatus Hadži, 1930 [Gardini, 2014].

CH: Chthonius baccettii was synonymised with C. carinthiacus Beier, 1951 [Gardini, 2004]. Ephippiochthonius elbanus was synonymised with E. nanus (Beier, 1953) [Gardini, 2013].

DE: Chthonius diophthalmus was synonymised with $C$. heterodactylus [Gardini, 2014].

HU: Cheiridium tetrophthalmum Daday, 1889 was removed from the synonymy of Geogarypus minor and treated as a synonym of Larca lata [Harvey, 2011]. Chthonius diophthalmus was synonymised with $C$. heterodactylus [Gardini, 2014]. Neobisium biharicum was synonymised with $N$. polonicum Rafalski, 1936 [Novák, Hörweg, 2017]. Geogarypus hungaricus (Tömösváry, 1883) was synonymised with Larca lata [Harvey et al., 2018]. 
SI: Chthonius ellingseni and C. brandmayri Callaini, 1986 were synonymised with C. raridentatus [Gardini, 2014].

SK: Chthonius diophthalmus and C. ksenemani were synonymised with $C$. heterodactylus [Gardini, 2014]. Diplotemnus insolitus was synonymised with $D$. balcanicus [Novák, Harvey, 2015].

\section{Results and Discussion}

The present checklist provides the pseudoscorpion diversity from eight countries of Central Europe Austria, Switzerland, the Czech Republic, Germany, Hungary, Poland, Slovenia and Slovakia (Table 1). A total of 125 species belonging to 30 genera and 10 families are documented in Central Europe (Tables 1,
2). Family Neobisiidae comprises the highest species number followed by the family Chthoniidae (Table 2). Austria and Switzerland represent the countries with the highest species diversity; by contrast the fauna of Slovenia, Poland, and the Czech Republic contain the lowest numbers of species (Table 2).

The diversity of pseudoscorpions in Central Europe includes species that are widespread throughout Europe, or have distributions restricted to certain territories. For example, some of the species are bounded mainly by Carpathian provinces (e.g. Chthonius hungaricus, Mundochthonius carpaticus, Neobisium carpaticum, N. polonicum, Roncus transsilvanicus) or Alpine provinces (e.g. Chthonius submontanus, Globo-

Table 1. Pseudoscorpion species list of Central European countries. Таблица 1. Видовой список ложноскорпионов стран Центральной Европы.

\begin{tabular}{|c|c|c|c|c|c|c|c|c|}
\hline \multirow{2}{*}{ Taxa } & \multicolumn{8}{|c|}{ Countries } \\
\hline & AT & $\mathbf{C H}$ & $\mathbf{C Z}$ & DE & HU & $\mathbf{P L}$ & SI & SK \\
\hline \multicolumn{9}{|l|}{ Chthoniidae Daday, 1888} \\
\hline Chthonius alpicola Beier, 1951 & $+*$ & & & + & & & & \\
\hline Chthonius carinthiacus Beier, 1951 & $+*$ & + & + & & + & & + & + \\
\hline Chthonius cavernarum Ellingsen, 1909 & & & & & & & + & \\
\hline Chthonius comottii Inzaghi, 1987 & & + & & & & & & \\
\hline Chthonius delmastroi Gardini, 2009 & & + & & & & & & \\
\hline Chthonius heterodactylus Tömösváry, 1883 & & & + & + & + & + & & $+^{*}$ \\
\hline Chthonius hungaricus Mahnert, 1980 & & & & & $+*$ & & & + \\
\hline Chthonius ischnocheles (Hermann, 1804) & + & + & + & + & + & + & & + \\
\hline Chthonius jugorum Beier, 1952 & + & & & & & & & \\
\hline Chthonius lanzai Caporiacco, 1947 & & + & & & & & & \\
\hline Chthonius orthodactylus (Leach, 1817) & + & + & + & + & + & & + & + \\
\hline Chthonius pusillus Beier, 1947 & $+*$ & & & & + & & + & \\
\hline Chthonius pygmaeus Beier, 1934 & + & & & & + & & + & $+*$ \\
\hline Chthonius raridentatus Hadži, 1930 & + & & & & & & $+*$ & \\
\hline Chthonius ressli Beier, 1956 & $+*$ & + & + & & + & & & + \\
\hline Chthonius rhodochelatus Hadži, 1933 & & + & & & & & + & \\
\hline Chthonius submontanus Beier, 1963 & $+*$ & + & & + & & & & \\
\hline Chthonius subterraneus Beier, 1931 & & & & & + & & & + \\
\hline Chthonius tenuis L. Koch, 1873 & + & + & + & + & & + & & + \\
\hline Ephippiochthonius boldorii (Beier, 1934) & + & + & & + & & & + & + \\
\hline Ephippiochthonius fuscimanus (Simon, 1900) & $+*$ & & + & + & + & + & & + \\
\hline Ephippiochthonius kewi (Gabbutt, 1966) & & & & + & & & & \\
\hline Ephippiochthonius microtuberculatus (Hadži, 1937) & + & & & & & & & \\
\hline Ephippiochthonius nanus (Beier, 1953) & & + & & & & & & \\
\hline Ephippiochthonius nidicola (Mahnert, 1979) & & $+*$ & & + & & & & \\
\hline Ephippiochthonius parmensis (Beier, 1963) & + & + & & + & & & + & \\
\hline Ephippiochthonius tetrachelatus (Preyssler, 1790) & + & + & $+*$ & $+*$ & + & + & + & + \\
\hline Ephippiochthonius tuberculatus (Hadži, 1937) & & & & + & + & & & + \\
\hline Globochthonius globifer (Simon, 1879) & & + & & & & & & \\
\hline Globochthonius poeninus (Mahnert, 1979) & & $+^{*}$ & & + & & & & \\
\hline Globochthonius spelaeophilus (Hadži, 1930) & & & & & & & $+*$ & \\
\hline Mundochthonius alpinus Beier, 1947 & $+*$ & & & & & & & \\
\hline Mundochthonius carpaticus Rafalski, 1948 & & & + & & + & $+*$ & & + \\
\hline Mundochthonius styriacus Beier, 1971 & $+*$ & + & + & + & & & & \\
\hline Geogarypidae Chamberlin, 1930 & & & & & & & & \\
\hline Geogarypus minor (L. Koch, 1873) & + & & & & & & & \\
\hline
\end{tabular}


Table 1 (continued).

Таблица 1 (продолжение).

\begin{tabular}{llllllll}
\hline \multirow{2}{*}{ Taxa } & \multicolumn{4}{c}{ Countries } & \multicolumn{4}{c}{ AT } & CH & CZ & DE & HU & PL & SI & SK \\
\hline
\end{tabular}

Neobisiidae Chamberlin, 1930

Microbisium brevifemoratum (Ellingsen, 1903)

Microbisium suecicum Lohmander, 1945

Neobisium (Blothrus) aueri Beier, 1962

Neobisium (B.) deschmanni (G. Joseph, 1882)

Neobisium (B.) pusillum Beier, 1939

Neobisium (B.) reimoseri (Beier, 1929)

Neobisium (B.) slovacum Gulička, 1977

Neobisium (B.) spelaeum (Schiödte, 1847)

Neobisium (B.) stygium Beier, 1931

Neobisium (Neobisium) aelleni Vachon, 1976

Neobisium (N.) beieri Verner, 1958

Neobisium (N.) brevidigitatum (Beier, 1928)

Neobisium (N.) caporiaccoi Heurtault-Rossi, 1966

Neobisium (N.) carcinoides (Hermann, 1804)

Neobisium (N.) carinthiacum Beier, 1939

Neobisium (N.) carpaticum Beier, 1935

Neobisium (N.) crassifemoratum (Beier, 1928)

Neobisium (N.) doderoi (Simon, 1896)

Neobisium (N.) dolicodactylum (Canestrini, 1874)

Neobisium (N.) dolomiticum Beier, 1952

Neobisium (N.) erythrodactylum (L. Koch, 1873)

Neobisium (N.) fuscimanum (C.L. Koch, 1843)

Neobisium (N.) galeatum Beier, 1953

Neobisium (N.) gineti Vachon, 1966

Neobisium (N.) helveticum Heurtault, 1971

Neobisium (N.) hermanni Beier, 1938

Neobisium (N.) inaequale Chamberlin, 1930

Neobisium (N.) jugorum (L. Koch, 1873)

Neobisium (N.) macrodactylum (Daday, 1888)

Neobisium (N.) minimum (Beier, 1928)

Neobisium (N.) noricum Beier, 1939

Neobisium (N.) polonicum Rafalski, 1936

Neobisium (N.) schenkeli (Strand, 1932)

Neobisium (N.) simile (L. Koch, 1873)

Neobisium (N.) simoni (L. Koch, 1873)

Neobisium (N.) strausaki Vachon, 1976

Neobisium (N.) sylvaticum (C.L. Koch, 1835)

Neobisium (N.) tothi Novák, 2017

Neobisium (N.) validum (L. Koch, 1873)

Roncus alpinus L. Koch, 1873

Roncus carinthiacus Beier, 1934

Roncus italicus (Simon, 1896)

Roncus jagababa Ćurčić, 1988

Roncus julianus Caporiacco, 1949

Roncus lubricus L. Koch, 1873

Roncus stussineri (Simon, 1881)

Roncus tenuis Hadži, 1933

Roncus transsilvanicus Beier, 1928

Syarinidae Chamberlin, 1930

Pseudoblothrus infernus Mahnert, 2011

Pseudoblothrus strinatii Vachon, 1954

Pseudoblothrus thiebaudi Vachon, 1969

Syarinus strandi (Ellingsen, 1901)
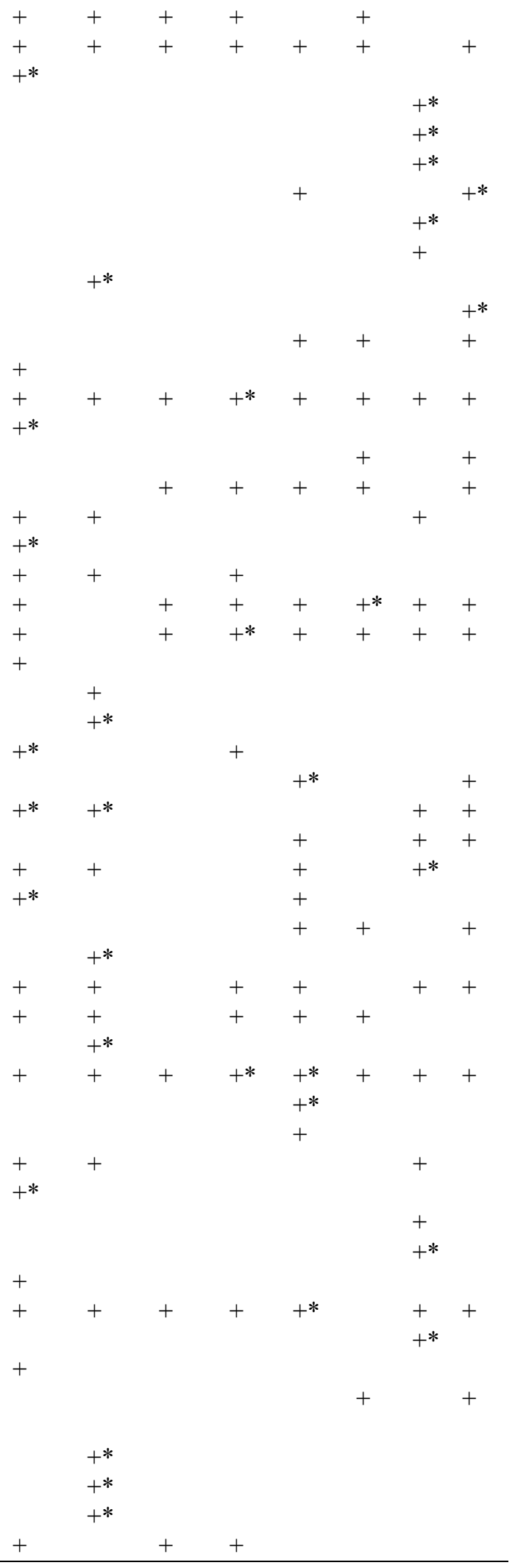
Table 1 (continued). Таблица 1 (продолжение).

\begin{tabular}{|c|c|c|c|c|c|c|c|c|}
\hline \multirow{2}{*}{ Taxa } & \multicolumn{8}{|c|}{ Countries } \\
\hline & $\mathbf{A T}$ & CH & $\mathbf{C Z}$ & DE & HU & PL & SI & SK \\
\hline \multicolumn{9}{|l|}{ Larcidae Harvey, 1992} \\
\hline Larca lata (Hansen, 1884) & + & & + & + & $+*$ & + & & + \\
\hline \multicolumn{9}{|l|}{ Cheiridiidae Hansen, 1894} \\
\hline Apocheiridium ferum (Simon, 1879) & + & + & + & + & & + & & \\
\hline Cheiridium museorum (Leach, 1817) & + & + & + & + & + & + & & + \\
\hline \multicolumn{9}{|l|}{ Atemnidae Kishida, 1929} \\
\hline Atemnus politus (Simon, 1878) & + & + & & & + & & & + \\
\hline Diplotemnus balcanicus (Redikorzev, 1928) & & & & & + & & & + \\
\hline \multicolumn{9}{|l|}{ Cheliferidae Risso, 1827} \\
\hline Beierochelifer peloponnesiacus (Beier, 1929) & & + & & & & & & + \\
\hline Chelifer cancroides (Linnaeus, 1758) & + & + & $+*$ & $+*$ & + & $+*$ & & + \\
\hline Dactylochelifer latreillii (Leach, 1817) & + & + & + & $+*$ & + & + & & + \\
\hline Hysterochelifer meridianus (L. Koch, 1873) & + & & & & & & & \\
\hline Hysterochelifer tuberculatus (Lucas, 1849) & & + & & & & & & \\
\hline Mesochelifer ressli Mahnert, 1981 & $+*$ & + & + & + & & + & & + \\
\hline Rhacochelifer euboicus Mahnert, 1977 & & & & & & & & + \\
\hline Rhacochelifer peculiaris (L. Koch, 1873) & + & + & & & $+*$ & & & + \\
\hline Rhacochelifer quadrimaculatus (Tömösváry, 1882) & & & & & & & & $+*$ \\
\hline \multicolumn{9}{|l|}{ Chernetidae Menge, 1855} \\
\hline Allochernes peregrinus Lohmander, 1939 & + & + & + & + & + & + & & + \\
\hline Allochernes powelli (Kew, 1916) & + & + & & + & + & & & + \\
\hline Allochernes solarii (Simon, 1898) & & & & & & & & + \\
\hline Allochernes wideri (C.L. Koch, 1843) & + & + & + & $+*$ & + & + & & + \\
\hline Anthrenochernes stellae Lohmander, 1939 & & & + & + & & + & & \\
\hline Chernes beieri Harvey, 1991 & & & & & & $+*$ & & \\
\hline Chernes cavicola G. Joseph, 1882 & & & & & & & $+*$ & \\
\hline Chernes cimicoides (Fabricius, 1793) & + & + & + & $+*$ & + & + & + & + \\
\hline Chernes hahnii (C.L. Koch, 1839) & + & + & + & $+*$ & + & + & & + \\
\hline Chernes montigenus (Simon, 1879) & + & $+*$ & & & + & & & \\
\hline Chernes nigrimanus Ellingsen, 1897 & + & + & + & + & & + & & \\
\hline Chernes similis (Beier, 1932) & + & & + & & + & + & & + \\
\hline Chernes vicinus (Beier, 1932) & $+*$ & + & + & + & & & & + \\
\hline Dendrochernes cyrneus (L. Koch, 1873) & + & + & + & + & $+*$ & + & & + \\
\hline Dinocheirus panzeri (C. L. Koch, 1837) & + & + & + & $+*$ & + & + & + & + \\
\hline Lamprochernes chyzeri (Tömösváry, 1883) & + & + & + & + & $+*$ & + & & $+*$ \\
\hline Lamprochernes nodosus (Schrank, 1803) & + & + & $+*$ & $+^{*}$ & $+*$ & + & & + \\
\hline Lasiochernes pilosus (Ellingsen, 1910) & + & + & & + & & & & + \\
\hline Pselaphochernes anachoreta (Simon, 1878) & & + & & & & & & \\
\hline Pselaphochernes dubius (O.Pickard-Cambridge, 1892) & & & & + & & + & & \\
\hline Pselaphochernes lacertosus (L. Koch, 1873) & & & & & + & & & \\
\hline Pselaphochernes scorpioides (Hermann, 1804) & + & + & + & + & $+*$ & + & & + \\
\hline \multicolumn{9}{|l|}{ Withiidae Chamberlin, 1931} \\
\hline Withius hispanus (L. Koch, 1873) & + & + & & & + & & & + \\
\hline Withius piger (Simon, 1878) & + & + & & + & + & & & \\
\hline
\end{tabular}

Abbreviations: AT - Austria, CH - Switzerland, CZ — the Czech Republic, DE — Germany, HU — Hungary, PL - Poland, SI Slovenia, SK — Slovakia, * — type localities.

chthonius poeninus, Neobisium dolomiticum). Some species restricted only to certain territories, may be considered as endemic. For example, Neobisium slovacum is endemic to the Slovak-Aggtelek Karst; Mundochthonius alpinus, Neobisium aueri, N. carinthiacum,
$N$. hermanni, and Roncus carinthiacus are endemic to the Austrian Alps; Neobisium aelleni, N. helveticum, N. strausaki and Pseudoblothrus infernus are endemic species in caves in Switzerland. Type localities for individual species are star-marked in Table 1. 
Table 2. Number of species/genera in each pseudoscorpion family in countries of Central Europe. Таблица 2. Число видов/родов в каждом семействе ложноскорпионов в странах Центральной Европы.

\begin{tabular}{lccccccccc}
\hline \multirow{2}{*}{ Families } & & \multicolumn{8}{c}{ Countries } \\
& AT & CH & CZ & DE & HU & PL & SI & SK & $\boldsymbol{\Sigma}$ \\
\hline Chthoniidae & $18 / 3$ & $18 / 4$ & $10 / 3$ & $15 / 4$ & $13 / 3$ & $6 / 3$ & $11 / 3$ & $14 / 3$ & $34 / 4$ \\
Geogarypidae & $1 / 1$ & $0 / 0$ & $0 / 0$ & $0 / 0$ & $0 / 0$ & $0 / 0$ & $0 / 0$ & $0 / 0$ & $1 / 1$ \\
Neobisiidae & $24 / 3$ & $17 / 3$ & $8 / 3$ & $12 / 3$ & $18 / 3$ & $12 / 3$ & $19 / 2$ & $17 / 3$ & $48 / 3$ \\
Syarinidae & $1 / 1$ & $3 / 1$ & $1 / 1$ & $1 / 1$ & $0 / 0$ & $0 / 0$ & $0 / 0$ & $0 / 0$ & $4 / 2$ \\
Larcidae & $1 / 1$ & $0 / 0$ & $1 / 1$ & $1 / 1$ & $1 / 1$ & $1 / 1$ & $0 / 0$ & $1 / 1$ & $1 / 1$ \\
Cheiridiidae & $2 / 2$ & $2 / 2$ & $2 / 2$ & $2 / 2$ & $1 / 1$ & $2 / 2$ & $0 / 0$ & $1 / 1$ & $2 / 2$ \\
Atemnidae & $1 / 1$ & $1 / 1$ & $0 / 0$ & $0 / 0$ & $2 / 2$ & $0 / 0$ & $0 / 0$ & $2 / 2$ & $2 / 2$ \\
Cheliferidae & $5 / 5$ & $6 / 6$ & $3 / 3$ & $3 / 3$ & $3 / 3$ & $3 / 3$ & $0 / 0$ & $7 / 5$ & $9 / 6$ \\
Chernetidae & $15 / 7$ & $15 / 7$ & $13 / 7$ & $15 / 8$ & $13 / 6$ & $14 / 7$ & $3 / 2$ & $14 / 7$ & $22 / 8$ \\
Withiidae & $2 / 1$ & $2 / 1$ & $0 / 0$ & $1 / 1$ & $2 / 1$ & $0 / 0$ & $0 / 0$ & $1 / 1$ & $2 / 1$ \\
\hline Species/genera total & $70 / 25$ & $64 / 25$ & $38 / 20$ & $50 / 23$ & $53 / 20$ & $38 / 19$ & $33 / 7$ & $57 / 23$ & $125 / 30$ \\
\hline
\end{tabular}

Abbreviations: AT - Austria, CH - Switzerland, CZ - the Czech Republic, DE - Germany, HU - Hungary, PL - Poland, SI Slovenia, SK - Slovakia, $\Sigma$ - number of species/genera for all considered countries.

\section{Pseudoscorpion diversity in the countries of Cen- tral Europe}

\section{Austria (AT)}

Mahnert [2004, 2011b] published checklists of Austrian pseudoscorpions containing 70 species of 25 genera and 10 families. Since then, only Neobisium deschmanni has been added into the Austrian fauna in the pseudoscorpion catalogue [Harvey, 2013b]. Harvey [2013b] mentioned the locality of Grotte von Luëg (Tirol, Austria) as the type locality for this species. In the original description, Joseph [1882] stated "in der grossen Grotte von Luëg in Unter-Krain" and Krain was mentioned as a locality of this species and also in other papers [Beier, 1932; Roewer, 1937; Wolf, 1938; Harvey, 1991]. Krain means Carniola, a historical region that comprised parts of present-day Slovenia. According to Schmidl [1854] Luëg or Lueg should be Predjama, a locality situated in Slovenia. Therefore, the species is here removed from the list of Austrian fauna and added to the fauna of Slovenia.

Austria, with 70 species of 25 genera and 10 families, represents the country with the highest species and genera numbers in Central Europe (Tables 1,2), also caused by the occurrence of pseudoscorpions endemic to the Alpine province. Mahnert [2009] documented seven endemic and two subendemic species for the Alpine province. Type localities of 17 species are situated in Austria (Table 1).

\section{Switzerland (CH)}

In the checklist of Central Europe, Blick [2004] mentioned 62 species of 25 genera and eight families for Switzerland. Blick [2004] included the species
Ephippiochthonius beieri (Lazzeroni, 1966) in the checklist, despite the fact that Lazzeroni later synonymised it with Ephippiochthonius tetrachelatus [Lazzeroni, 1969]. After the checklist by Blick [2004], three species were recorded in Switzerland for the first time, two of them new to science - Chthonius rhodochelatus [Gardini, 2009a], C. delmastroi [Gardini, 2009a] and Pseudoblothrus infernus [Mahnert, 2011a].

Summarising all data, the present checklist of Swiss pseudoscorpions includes 64 species of 25 genera and eight families; type localities of 11 species are situated in Switzerland (Tables 1,2). Switzerland is the country with the second-highest pseudoscorpion diversity in Central Europe (Table 2). From the protection point of view, some troglobitic species may be considered as endemic to Switzerland (e.g. Neobisium aelleni, Neobisium helveticum, Neobisium strausaki, Pseudoblothrus infernus).

The catalogue of Pseudoscorpions of the World [Harvey, 2013b] includes only 43 species of 21 genera and eight families.

\section{Czech Republic (CZ)}

The last pseudoscorpion checklist of the Czech Republic was published by Christophoryová et al. [2012b] and includes 38 species of 20 genera and seven families.

The species number has not changed after the checklist by Christophoryová et al. [2012b] (Tables 1, 2). Type localities of three species are situated in the country (Table 1). From the protection point of view, the most important species is the rare Anthrenochernes stellae (Table 1). This species is red-listed not only in the Czech Republic but also in other countries of its occurrence [Fjellberg, Lissner, 2016; Št’áhlavský, 2017]. 
Ephippiochthonius kewi and Chthonius heterodactylus were excluded from the fauna by Christophoryová et al. [2012b], but these species are still included in the catalogue of Pseudoscorpions of the World [Harvey, 2013b] for the Czech Republic.

\section{Germany (DE)}

In the checklist of Central Europe, Blick [2004] presented 48 species from 22 genera and eight families for Germany. After the checklist [Blick, 2004], the latest recorded species, as well as genus, for Germany was Globochthonius poeninus [Muster et al., 2008].

The last updated pseudoscorpion list for Germany includes 49 species of 23 genera and eight families [Muster, Blick, 2016]. Several differences between the species lists [Blick, 2004; Muster, Blick, 2016] are commented on here. Neobisium hermanni was reported from Germany as far as back in 1969 [Kreissl, 1969] but was not included in the list for Germany since the last list [Muster, Blick, 2016]. The presence of Ephippiochthonius kewi in Germany is doubtful. The species was recorded firstly in Germany by Drogla [1992] on the basis of several specimens among the many specimens of E. tetrachelatus from one study area. They differ from E. tetrachelatus by the presence of additional short lateral microsetae on the posterior carapace margin; other morphological and morphometric characters overlap. The close relationship of these two species was considered also in other papers (e.g. Drogla, 2004; Drogla, Lippold, 2004). Later, van den Tooren [2011] revised the differential characters between these species from the Netherlands and found out that they could only be separated by using the setae number on the posterior genital operculum in both females and males. The status of the species remains doubtful, since Muster \& Blick [2016] did not revise the German material (T. Blick, pers. comm.). The species Chernes beieri and Ephippiochthonius parmensis were excluded from the list [Muster, Blick, 2016]. The species $C$. beieri was originally described as Chernes pallidus Beier, 1936 from the locality of Kauffung, Schlesien in Poland [Beier, 1936]. Harvey [1991] stated that the locality is situated near Kassel in Germany, but at present Kauffung (meaning Wojcieszów) lies in Poland. Ephippiochthonius parmensis was found in the city park and it was assumed to have been introduced in the root balls of Rhododendron sp. [Drogla, 1990]. The species has not been observed over several years and there is no other evidence that the species can be regarded as established in Germany (T. Blick, pers. comm.). It is here included in the pseudoscorpion fauna of Germany in the same way as other introduced species in other countries.

The present checklist includes 50 species from 23 genera and eight families; type localities of 11 species are situated in Germany (Tables 1, 2). From the faunistic and geographic points of view, three species are interesting. The records of the rare species Ephippio- chthonius nidicola and G. poeninus in Germany represent the first records outside of the Swiss Alps. Initially, they were regarded as Swiss-endemic [Muster, 2004; Muster et al., 2008]. Another rare species, Anthrenochernes stellae, is considered to be endangered in Germany and is protected by the European Habitat Directive [Ssymank, Muster, 2010; Muster, Blick, 2016].

The catalogue of Pseudoscorpions of the World [Harvey, 2013b] still contains the excluded species $C$. beieri [Muster, Blick, 2016], and does not include $N$. hermanni [Kreissl, 1969].

\section{Hungary (HU)}

Kárpáthegyi [2007a, b] listed in the checklists of Hungarian pseudoscorpions 40 species of 18 genera and eight families. After the checklists [Kárpáthegyi, $2007 \mathrm{a}, \mathrm{b}$ ], four synonymisation were made [Harvey, 2011; Gardini, 2014; Novák, Hörweg, 2017; Harvey et al., 2018] and 13 new species records for Hungarian fauna were discovered, one of them was new to science - Chthonius carinthiacus, Mundochthonius carpaticus and Chernes similis [Novák, 2012]; Neobisium polonicum [Novák, 2013]; C. ressli [Novák, Kutasi, 2014]; N. brevidigitatum and Withius hispanus [Novák, 2015]; Diplotemnus balcanicus [Novák, Harvey, 2015]; $N$. noricum and N. tothi [Novák, 2017]; C. pusillus, Ephippiochthonius fuscimanus and $N$. cf. minimum [Novák, 2018]. Beier [1963] reported occurrence of the species Neobisium crassifemoratum from Eastern Hungary without concrete locality data. Kárpáthegyi [2007a, b] overlooked this occurrence, and Novák [2012] later added the species into the Hungarian fauna with its first faunistic data.

Only two questionable records of Neobisium simo$n i$ are known from Hungary [Tömösváry, 1883; Daday, 1918]. Tömösváry [1883] listed $N$. simoni without detailed locality data. Daday [1918] mentioned the locality "Hunyad", which was a county of the Kingdom of Hungary, today in Romanian Transylvania. In addition, the specimens of $N$. simoni have not been found in the Hungarian Natural History Museum (J. Novák, pers. comm.). The occurrence of the species is therefore doubtful and needs to be confirmed.

Summarising all data, 53 species of 20 genera and eight families are documented for Hungary (Tables 1, $2)$. Type localities of 11 species are situated in Hungary (Table 1). From the faunistic and geographic points of view, two species are interesting: troglobiont $N$. slovacum is endemic to the Slovak-Aggtelek Karst found in Meteor cave [Ducháč, Mlejnek, 2000] and Chthonius hungaricus is restricted to inner Western Carpathians and Transylvania [Gardini, 2014].

In the catalogue of Pseudoscorpions of the World [Harvey, 2013b], 46 species of 19 genera and nine families are included. It still includes species that were excluded from Hungarian fauna by Novák [2012] and Harvey et al. [2018], i.e. Geogarypus hungaricus, Microbisium manicatum (L. Koch, 1873), Neobisium seminudum (Daday et Tömösváry, 1880), N. minutum 
(Tömösváry, 1883), Roncus euchirus (Simon, 1879) and Rhacochelifer quadrimaculatus. In contrast, 13 species are not included (Chthonius carinthiacus, $C$. pusillus, C. ressli, Ephippiochthonius fuscimanus, Mundochthonius carpaticus, Neobisium brevidigitatum, $N$. minimum, N. noricum, N. polonicum, N. tothi, Diplotemnus balcanicus, Chernes similis and Withius hispanus).

\section{Poland (PL)}

The first comprehensive pseudoscorpion catalogue of Poland was published by Rafalski [1967] and includes 39 species from 18 genera and six families. The occurrence of three species was questioned by Rafalski [1967], and they were not listed later in the catalogue of Jędryczkowski [2014]. These questionable species are discussed here. Beier [1936] described Neobisium vulpinum Beier, 1936 from Krkonoše, western Sudetenland (a mountain range at present within parts of the Czech Republic and Poland). Beier [1963] later synonymised this species with Neobisium minutum (Tömösváry, 1882) and stated that the locality details of the species were erroneous. The next questionable species was Neobisium jugorum with distribution in the Tatry Mts. [Rafalski, 1967]. According to Verner [1960], the species was found on Ždiarska Vidla hill situated in the Belianske Tatry Mts. in Slovakia. In the case of the third species, Neobisium simile, Rafalski [1967] stated that it was probably a misidentification of Neobisium muscorum germanicum Beier, 1931 (actually a synonym of Neobisium carcinoides). Only Mesochelifer ressli was added to the Poland fauna [Jędryczkowski, 1985].

All above-mentioned changes were summarised in the updated pseudoscorpion list of Poland [Jędryczkowski, 2014]. The present checklist for Poland contains 38 species of 19 genera and six families (Tables $1,2)$. Type localities of four species are situated in Poland (Table 1). Two species, Mundochthonius carpaticus and Neobisium polonicum, belong to Carpathian elements.

In the catalogue of Pseudoscorpions of the World [Harvey, 2013b] the species N. minutum and N. simile are still listed in Polish fauna, and two species, Ephippiochthonius fuscimanus and Pselaphochernes $d u$ bius, are not included.

\section{Slovenia (SI)}

The pseudoscorpion diversity of Slovenia was summarised in the catalogue of Pseudoscorpions of the World [Harvey, 2013b] and included 31 species from seven genera and three families. Including later synonyms of Chthonius raridentatus [Gardini, 2014], 29 species are valid. Recently, three new species were recorded for Slovenian fauna: Ephippiochthonius boldorii, E. parmensis [Gardini, 2013] and Chthonius pusillus [Gardini, 2014]. Moreover, based on the correction of type locality stated by Joseph [1882], the species Neobisium deschmanni has been added into the Slovenian fauna (see Austria).
Summarising all data, pseudoscorpion diversity of Slovenia consists of 33 species belonging to seven genera and three families (Tables 1,2). Type localities of 10 species are situated in Slovenia (Table 1). Two rare species occurring in Slovenia, Roncus jagababa and Chernes cavicola, may be considered as endemic. Within the countries of Central Europe, Slovenia has the lowest species diversity.

\section{Slovakia (SK)}

The latest published checklist of Slovakian pseudoscorpions contained 51 species of 21 genera and seven families [Christophoryová et al., 2012b]. Two synonymisation were made after that [Gardini, 2014; Novák, Harvey, 2015] and seven species were quoted as new records for Slovakian fauna: Chthonius carinthiacus and Ephippiochthonius tuberculatus [Christophoryová et al., 2011c], Allochernes powelli [Christophoryová et al., 2011b], Withius hispanus [Christophoryová et al., 2012a], Beierochelifer peloponnesiacus [Krajčovičová, Christophoryová, 2017], Rhacochelifer euboicus (misidentified by Krajčovičová et al. [2017] with $R$. disjunctus (L. Koch, 1873) and later corrected by Hernández-Corral et al. [2018]), and Allochernes solarii [Červená et al., 2018]. The status of several species: Chthonius subterraneus, Neobisium macrodactylum, N. simile, Roncus transsilvanicus, Rhacochelifer peculiaris and $R$. quadrimaculatus, remains questionable [Christophoryová et al., 2012b], mainly because of no extant specimens available.

Summarising all data, pseudoscorpions in Slovakia are represented by 57 species of 23 genera and eight families (Tables 1,2); type localities of six species are situated in Slovakia (Table 1). Two rare species occur in Slovakia: the endemic Neobisium beieri is known only from the Vel'ká Fatra Mts. and the troglobiont Neobisium slovacum is endemic to the Slovak-Aggtelek Karts, which simultaneously represents the northernmost occurrence of the subgenus Blothrus Schiödte, 1847 in Europe [Červená et al., 2019]. The following species are considered as the Carpathian elements: Chthonius hungaricus, Mundochthonius carpaticus, Neobisium carpaticum, N. polonicum, and Roncus transsilvanicus. Three species may be introduced: Diplotemnus balcanicus, Beierochelifer peloponnesiacus and Rhacochelifer euboicus.

The catalogue of Pseudoscorpions of the World [Harvey, 2013b] still contains species that were either synonymised (Chthonius ksenemani, Diplotemnus insolitus) or excluded from the pseudoscorpion fauna of Slovakia (Roncus alpinus, Pselaphochernes dubius) [Christophoryová et al., 2012b; Gardini, 2014]. On the other hand, four species - Beierochelifer pelopponesiacus, Rhacochelifer euboicus, Allochernes solarii, Withius hispanus - are not included.

Acknowledgements. We would like to thank our colleagues for their goodwill and prompt approaches, conducive opinions and explanations, namely: Theo Blick (Germany), Giulio Gardini (Italy), Mark S. Harvey (Australia), 
Christoph Hörweg (Austria), Wojciech B. Jędryczkowski (Poland), and János Novák (Hungary). The project was financially supported by VEGA 2/0032/19 and APVV-150147.

\section{References}

Beier M. 1932. Pseudoscorpionidea I. Subord. Chthoniinea et Neobisiinea // Das Tierreich. Ldg.57. S.1-258.

Beier M. 1936. Zwei neue Pseudoskorpione aus deutschen Kleinsäuger-Höhlen // Zoologischer Anzeiger. Bd.114. H.3/4. S.8587.

Beier M. 1963. Ordnung Pseudoscorpionidea (Afterskorpione) // Bestimmungsbücher zur Bodenfauna Europas. Bd.1. Berlin: Akademie-Verlag. $313 \mathrm{~S}$.

Blick T. 2004. Einführung in die Checklisten der Spinnentiere der AraGes. Introduction to the checklists of arachnids by the AraGes (Arachnida: Araneae, Opiliones, Pseudoscorpiones, Scorpiones, Palpigradi). Arachnologische Gesellschaft (AraGes). https://arages.de/arachnologie-vernetzt/service-und-kontakt/ checklisten.html (last access 04.10.2019).

Christophoryová J., Fend’a P., Krištofík J. 2011a. Chthonius hungaricus and Larca lata new to the fauna of Slovakia (Pseudoscorpiones: Chthoniidae, Larcidae) // Arachnologische Mitteilungen. Vol.41. P.1-6. https://doi.org/10.5431/aramit4101

Christophoryová J., Gardini G., Énekesová E. 2012a. Withius hispanus new to the fauna of Slovakia (Pseudoscorpiones: Withiidae) // Arachnologische Mitteilungen. Vol.44. P.10-13. https://doi.org/10.5431/aramit4403

Christophoryová J., Gardini G., Korenko S. 2011b. Allochernes powelli new to the fauna of Slovakia (Pseudoscorpiones: Chernetidae) // Folia faunistica Slovaca. Vol.16. No.2. P.67-70.

Christophoryová J., Mock A., Luptáčik P. 2011c. Chthonius (Chthonius) carinthiacus and Chthonius (Ephippiochthonius) tuberculatus new to the fauna of Slovakia (Pseudoscorpiones: Chthoniidae) // Arachnologische Mitteilungen. Vol.42. P.23-28. https://doi.org/10.5431/aramit4206

Christophoryová J., Št'áhlavský F., Fedor P. 2011d. An updated identification key to the pseudoscorpions (Arachnida: Pseudoscorpiones) of the Czech Republic and Slovakia // Zootaxa. Vol.2876. P.35-48. http://doi.org/10.11646/zootaxa.2876.1.4

Christophoryová J., Štáhlavský F., Krumpál M., Fedor P. 2012b. Pseudoscorpions of the Czech Republic and Slovakia: An annotated and revised checklist (Arachnida: Pseudoscorpiones) // North-Western Journal of Zoology. Vol.8. No.1. P.1-21.

Červená M., Christophoryová J., Purkart A., Krajčovičová K. 2018. Allochernes solarii (Pseudoscorpiones: Chernetidae) newly recorded from ant nests in Slovakia // Arachnologische Mitteilungen. Vol.56. P.40-44. https://doi.org/10.30963/aramit5607

Červená M., Štáhlavský F., Papáč V., Kováč L., Christophoryová J. 2019. Morphological and cytogenetic characteristics of $\mathrm{NeO}$ bisium (Blothrus) slovacum Gulička, 1977 (Pseudoscorpiones, Neobisiidae), the northernmost troglobitic species of the subgenus Blothrus in Europe // ZooKeys. Vol.817. P.113-130. https://doi.org/10.3897/zookeys.817.27189

Daday E. 1918. Ordo Pseudoscorpiones // J. Paszlavszky (ed.). A Magyar Birodalom Állatvilága. Fauna Regni Hungariae. Vol.III. Budapest: Regia Societas Scientiarum Naturalium Hungarica. P.1-2.

Drogla R. 1990. Die Pseudoskorpione des Museum der Natur Gotha (Arachnida, Pseudoscorpiones) // Abhandlungen und Berichte, Museum der Natur Gotha. Bd.16. S.97-102.

Drogla R. 1992. Pseudoskorpione des Naturschutzgebietes "Schwellenburg" bei Erfurt/Thüringen (Arachnida, Pseudoscorpiones) // Veröffentlichungen Naturkundemuseum Erfurt. Bd.1992. S.62-66.

Drogla R. 2004. Kommentierte Checkliste der Pseudoskorpione Thüringens (Arachnida, Pseudoscorpiones) // M. Hartmann, R. Bellstedt (Hrsg.). Check-Listen Thüringer Insekten und Spinnentiere. Teil 12. Jena: Thüringer Entomologenverband e.V. S.5-8.
Drogla R., Lippold K. 2004. Zur Kenntnis der PseudoscorpionFauna von Ost-deutschland (Arachnida, Pseudoscorpiones) // Arachnologische Mitteilungen. Vol.27/28. P.1-54. https:// doi.org/10.5431/aramit2701

Ducháč V., Mlejnek R. 2000. Records of the pseudoscorpion Neobisium (Blothrus) slovacum (Neobisiidae) in caves and chasms of the Slovak Karst // A. Mock, L. Kováč, M. Fulín (eds.). Fauna jaskýň (Cave Fauna). Košice: East Slovakian Museum. P.15-20.

Fjellberg A., Lissner J. 2016. Anthrenochernes stellae Lohmander, 1939 (Pseudoscorpiones, Chernetidae) new to the Norway // Norwegian Journal of Entomology. Vol.63. P.4-5.

Gardini G. 2004. Note faunistiche e tassonomiche sugli Pseudoscorpioni (Arachnida) epigei (Pseudoscorpioni d'Italia XXXV) // Memorie del Museo Civico di Storia Naturale di Verona, 2. Serie, Monografie Naturalistiche. Vol.1. P.123-133.

Gardini G. 2009a. Chthonius (C.) delmastroi n. sp. della Alpi occidentali e del Piemonte e ridescrizione di Chthonius $(C$.) tenuis L. Koch, 1873 e di C. (C.) submontanus Beier, 1963 (Pseudoscorpiones Chthoniidae) // Rivista Piemontese di Storia Naturale. Vol.30. P.25-51.

Gardini G. 2009b. Neotype fixation and redescription of Chthonius tetrachelatus (Preyssler, 1790), type species of the subgenus Ephippiochthonius Beier, 1930 (Pseudoscorpiones: Chthoniidae) // Klapalekiana. Vol.45. P.23-31.

Gardini G. 2013. A revision of the species of the pseudoscorpion subgenus Chthonius (Ephippiochthonius) (Arachnida, Pseudoscorpiones, Chthoniidae) from Italy and neighbouring areas // Zootaxa. Vol.3655. No.1. P.1-151. https://doi.org/10.11646/ zootaxa. 3655.1 .1

Gardini G. 2014. The species of the Chthonius heterodactylus group (Arachnida, Pseudoscorpiones, Chthoniidae) from the eastern Alps and the Carpathians // Zootaxa. Vol.3887. No.2. P.101-137. https://doi.org/10.11646/zootaxa.3887.2.1

Gardini G., Galli L., Zinni M. 2017. Redescription of Geogarypus minor, type species of the genus Geogarypus, and description of a new species from Italy (Pseudoscorpiones: Geogarypidae) // Journal of Arachnology. Vol.45. P.424-443.

Harvey M.S. 1991. Catalogue of the Pseudoscorpionida // Manchester and New York: Manchester University Press. 726 p.

Harvey M.S. 2007. The smaller arachnid orders: diversity, descriptions and distributions from Linnaeus to the present (1758 to 2007) // Zootaxa. Vol.1668. P.363-380.

Harvey M.S. 2011. Cheiridium tetrophthalmum Daday, a new synonym of Larca lata (Hansen) (Pseudoscorpiones, Larcidae) // Arachnologische Mitteilungen. Vol.41. P.31-33. https://doi.org/ 10.5431/aramit4104

Harvey M.S. 2013a. Order Pseudoscorpiones. Animal biodiversity: An outline of higher-level classification and survey of taxonomic richness (Addenda 2013) // Zootaxa. Vol.3703. No.1. P.34-35. https://doi.org/10.11646/zootaxa.3703.1.8

Harvey M.S. 2013b. Pseudoscorpions of the World. Version 3.0. Western Australian Museum Pert. http://museum.wa.gov.au/ catalogues-beta/pseudoscorpions/ (last access 04.10.2019).

Harvey M.S., Gardini G., Novák J. 2019. Case 3736 - Garypus latus Hansen, 1884 (currently Larca lata; Arachnida, Pseudoscorpiones): proposed precedence over Garypus hungaricus Tömösváry, 1882 // Bulletin of Zoological Nomenclature. Vol.75. P.16-20. https://doi.org/10.21805/bzn.v75.a007

Hernández-Corral J., Zaragoza J.A., Micó E. 2018. New species of Pseudoscorpiones (Arachnida) from tree hollows in a Mediterranean oak forest in Spain // Zootaxa. Vol.4497. No.2. P.201225. https://doi.org/10.11646/zootaxa.4497.2.3

Jedryczkowski W.B. 1985. Zaleszczotki (Pseudoscorpiones) Mazowsza // Fragmenta Faunistica Musei Zoologici Polonici. Vol.29. P.77-83.

Jędryczkowski W.B. 2014. Lista gatunków zaleszczotków (Pseudoscorpionidea) Polski. http://www.arachnologia.edu.pl/pl/gatunki/17-zaleszczotki-polski.html (last access 04.10.2019).

Joseph G. 1882. Systematiches Verzeichniss der in den TropfsteinGrotten von Krain einheimischen Arthropoden nebst Diagnosen der vom Verfasser entdeckten und bisher noch nicht bes- 
chriebenen Arten // Berliner Entomologische Zeitschrift. Bd.26. H.1. S.1-50.

Judson M.L.I. 2018. Comment (Case 3736) - Revised publication dates and disagreement with the proposal to give Larca lata (Hansen, 1885) precedence over L. hungarica (Tömösváry, 1883) (Arachnida, Pseudoscorpiones) // Bulletin of Zoological Nomenclature. Vol.75. P.16-20. http://doi.org/10.21805/ bzn.v75.a053

Kárpáthegyi P. 2007a. Check list of the Hungarian Pseudoscorpiones // Folia Historico Naturalia Musei Matraensis. Vol.31. P.91-97.

Kárpáthegyi P. 2007b. Pseudoscorpions of Hungary // Folia Historica Naturalia Musei Matraensis. Vol.31. P.81-90.

Krajčovičová K., Christophoryová J. 2017. First record of Beierochelifer Mahnert, 1977 (Pseudoscorpiones: Cheliferidae) from Slovakia // Check List. Vol.13. No.2. P.1-4. https://doi.org/ 10.15560/13.2.2074

Krajčovičová K., Christophoryová J., Mahnert V. 2017. Rhacochelifer disjunctus (Pseudoscorpiones: Cheliferidae) new to the fauna of Slovakia // Arachnologische Mitteilungen. Vol.53. P.38-42. https://doi.org/10.5431/aramit5306

Kreissl E. 1969. Ein weiterer steirischer Fund des Höhlen-Pseudoskorpions Neobisium hermanni Beier (Arachnoidea-Pseudoscorp.) // Mitteilungen der Abteilung für Zoologie und Botanik am Landesmuseum Joanneum in Graz. Bd.31. S.43-44.

Lazzeroni G. 1969. Contributo alla conoscenza degli pseudoscorpioni della regione Veronese. (Ricerche sugli Pseudoscorpioni. IV) // Memorie del Museo Civico di Storia Naturale di Verona. Vol.16. P.379-418.

Mahnert V. 2004. Die Pseudoskorpione Österreichs (Arachnida, Pseudoscorpiones) // Denisia. Bd.12. S.459-471.

Mahnert V. 2009. Pseudoscorpiones (Pseudoskorpione) // W Rabitsch, F. Essl (Hrsg.). Endemiten - Kostbarkeiten in Österreichs Pflanzen und Tierwelt. Klagenfurt und Wien: Naturwissenschaftlicher Verein für Kärnten. S.501-508.

Mahnert V. 2011a. Pseudoblothrus infernus sp. n. (Pseudoscorpiones, Syarinidae) from the Hölloch cave (Schwyz, Switzerland), with new records of Pseudoblothrus strinatii Vachon from Switzerland and France // Revue Suisse de Zoologie. T.118. Fasc.1. P.11-15.

Mahnert V. 2011b. Pseudoscorpiones (Arachnida) // R. Schuster (Hrsg.). Checklisten der Fauna Österreichs. Nr.5. Wien: Verlag der Österreichischen Akademie der Wissenschaften. S.28-39.

Muster C. 2004. Ein Endemit auf Abwegen: Chthonius (Ephippiochthonius) nidicola neu für Deutschland (Pseudoscorpiones, Chthoniidae)// Arachnologische Mitteilungen. Vol.27/28. P.6873. https://doi.org/10.5431/aramit2703

Muster C., Blick T. 2016. Rote Liste und Gesamtartenliste der Pseudoskorpione (Arachnida: Pseudoscorpiones) Deutschland // H. Gruttke, M. Binot-Hafke, S. Balzer, H. Haupt, N. Hofbauer, G. Ludwig, G. Matzke-Hajek, M. Ries (Hrsg.). Rote Liste gefährdeter Tiere, Pflanzen und Pilze Deutschlands Band 4: Wirbellose Tiere (Teil 2). Münster: Naturschutz und Biologische Viefalt. S.539-561.

Muster C., Blick T., Höfer H. 2008. Chthonius (Ephippiochthonius) poeninus - ein "Schweizer Endemit" in den Allgäuer Alpen (Pseudoscorpiones: Chthoniidae) // Arachnologische Mitteilungen. Vol.36. P.21-25. https://doi.org/10.5431/ aramit3604

Nassirkhani M. 2018. A redescription of Pselaphochernes scorpioides (Hermann) (Pseudoscorpiones; Chernetidae) // International Journal of Avian \& Wildlife Biology. Vol.3. No.3. P.240243. https://doi.org/10.15406/ijawb.2018.03.00092

Novák J. 2012. New records of pseudoscorpions for the fauna of the Bükk Mts., Northeast Hungary (Arachnida: Pseudoscorpiones) // Opuscula Zoologica Budapest. Vol.43. No.1. P.57-65.
Novák J. 2013. First records of Larca lata (Hansen, 1884) and Neobisium biharicum Beier, 1939 in Hungary // Opuscula Zoologica Budapest. Vol.44. No.2. P.161-166.

Novák J. 2015. New records for the pseudoscorpion fauna of the Bakony Mts, Hungary (Arachnida: Pseudoscorpiones) // Opuscula Zoologica Budapest. Vol.46. No.2. P.153-158.

Novák J. 2017. Neobisium (N.) tothi sp. nov., a new species from Hungary and Romania, and first records of Neobisium $(N$.) noricum Beier, 1939 from Hungary (Pseudoscorpiones: Neobisiidae) // Turkish Journal of Zoology. Vol.41. P.416-423. https://doi.org/10.3906/zoo-1607-19

Novák J. 2018. New data on the pseudoscorpion fauna of Hungary (Arachnida: Pseudoscorpiones) // Acta Societatis Zoologicae Bohemicae. Vol.82. No.3-4. P.97-107.

Novák J., Harvey M.S. 2015. The identity of pseudoscorpions of the genus Diplotemnus (Pseudoscorpiones: Atemnidae) from Europe and Asia // North-Western Journal of Zoology. Vol.11. No.2. P.316-323.

Novák J., Hörweg C. 2017. Redescription of three species of the genus Neobisium from the Balkans and the Carpathians (Arachnida: Pseudoscorpiones) // Acta Zoologica Academiae Scientiarum Hungaricae. Vol.63. No.3. P.277-292. https://doi.org/ 10.17109/AZH.63.3.277.2017

Novák J., Kutasi Cs. 2014. New data on the Pseudoscorpion fauna of the caves of the Bakony Mountains, Hungary // Opuscula Zoologica Budapest. Vol.45. No.2. P.189-194.

Rafalski J. 1967. Katalog Fauny Polski. Zaleszczotki — Pseudoscorpionidea. Warszawa: Państwowe Wydawnistwo Naukowe. $36 \mathrm{p}$.

Roewer C.FR. 1937. Dr. H.G. Bronns Klassen und Ordnungen des Tierreichs. Bd.5: Arthropoda, 1. Teil: Chelonethi oder Pseudoskorpione. Leipzig: Akademische Verlagsgesellschaft m.b.H. $354 \mathrm{~S}$.

Schmidl A.A. 1854. Zur Höhlenkunde des Karstes. Die Grotten und Höhlen von Adelsberg, Lueg, Planina und Laas. Wien: Akademie der Wissenschaften. $317 \mathrm{~S}$.

Ssymank A., Muster C. 2010. Anthrenochernes stellae Lohmander, 1939 - ein Pseudoskorpion des Anhangs II der FFH-Richtlinie neu für das Saarland // Abhandlungen der Delattinia. Bd.35/ 36. S.387-391.

Št'áhlavský F. 2017. Pseudoscorpiones (štírci) // R. Hejda, J. Farkač, K. Chobot (eds.). Červený seznam ohrožených druhů České Republiky. Bezobratlí. Praha: Agentura ochrany př́rody a krajiny ČR. P.78-79.

Tooren van den D. 2011. Notes on the identification of the pseudoscorpions Chthonius tetrachelatus and C. kewi (Pseudoscorpiones: Chthoniidae) // Nederlandse Faunistische Mededelingen. Vol.35. P.87-90.

Tömösváry Ö. 1883. A Magyar fauna álskorpiói [1882] // Magyar Tudományos Akadémia Matematikai és Természettudományi Közlemények. Vol.18. No.7. P.135-256.

Verner P.H. 1960. Příspěvek k poznání štírků Československa // Věštník Československé Zoologické Společnosti. Vol.24. No.2. P.167-169.

Wolf B. 1938. Animalium Cavernarum Catalogus. Vol.3. TierCatalog. Gravenhage: W. Junk, Verlag für Naturwissenschaften. $918 \mathrm{~S}$.

Zaragoza J.A. 2017. Revision of the Ephippiochthonius complex in the Iberian Peninsula, Balearic Islands and Macaronesia, with proposed changes to the status of the Chthonius subgenera (Pseudoscorpiones, Chthoniidae) // Zootaxa. Vol.4246. No.1. P.1-221. https://doi.org/10.11646/zootaxa.4246.1.1

Responsible editor K.G. Mikhailov 